\title{
Issues in halal food product labelling: a conceptual paper
}

\author{
$1,{ }^{*}$ Osman, S., ${ }^{2}$ Ab. Rahman, S. and ${ }^{3}$ Jalil, A. \\ ${ }^{1}$ Faculty of Syariah and Law, Universiti Sains Islam Malaysia, Bandar Baru Nilai, 71800 Nilai, Negeri \\ Sembilan, Malaysia \\ ${ }^{2}$ Faculty of Economics and Management, Universiti Putra Malaysia, 43400 UPM Serdang, Malaysia \\ ${ }^{3}$ Faculty of Economics and Muamalat, Universiti Sains Islam Malaysia, Bandar Baru Nilai, 71800 Nilai, \\ Negeri Sembilan, Malaysia
}

Article history:

Received: 9 August 2019

Received in revised form: 25

November 2019

Accepted: 1 February 2020

Available Online: 10

February 2020

Keywords:

Halal,

Halal food products,

Trademark,

Label,

Islamic attributes

DOI:

https://doi.org/10.26656/fr.2017.4(S1).S15

\begin{abstract}
The paper was aimed to uncover the issues encountered on Halal Food Product labelling to prevent the misuse of Islamic attributes in food products labelling and to ensure the appropriate trademarks, terms, and label used on the packaging and marketing strategy. The method used for this conceptual paper was from literature reviews from journal articles, thesis, proceedings and conferences, books, and online news, which are related to the keywords and research area. Trademarks and labels are among the crucial elements in marketing, which enable the consumer to differentiate the quality, the ingredients and will affect the consumers' buying choice. Recently there is a trend of using Islamic attributes in food product labelling as trademarks to attract Muslim consumers. The issues encountered on halal food product labelling are the use of Quranic verses on the drink, the term "Sunnah food", using Islamic terms such as "Masjid", "Mukmin", and others in food products' trademark and label. The consumers were deceived into thinking that these products have extra benefits as compared to others due to Islamic attributes they have. Thus, there is a need for an in-depth study on these issues since there is no clear and specific guideline on this matter.
\end{abstract}

\section{Introduction}

Religious belief is one of the factors that influence purchase decisions in food products as different religious groups prohibit certain foods from being consumed by the followers (Schiffman and Kanuk, 2010; Ramli and Jamaludin, 2016 in Ab Talib and Mohd Johan, 2012). The use of Islamic elements in marketing and labelling of food products is increasingly popular and widespread in the Malaysian market. This phenomenon is due to the high demand from the consumer owing to various factors such as the current interest of people towards Islam is so high that whatever it is claimed is the efficacy of the Qur'an, so many believe that without prior inspection (Ahmad, Yakub, Razzak et al., 2015). The consumption of Sunnah food had become a trend (Othman et al., 2016) this is because products based on "Sunnah food" or Ruqyah food and drink (being read al-Quran verses onto them) are often referred to as the best food. They believe that these products may cure certain diseases such as mysterious diseases or "santau" (Deuraseh and Mohd Tohar, 2008; Ismail, 2012; Zain, 2013a). The Malaysian Muslim community, are weakened when it comes to the sunnah of the Holy Prophet (PBUH) with regard to advantages of practicing the sunnah and the health benefits that will be obtained from the food consumption, has also led to the increasing production of sunnah food products in the market (Ahmad, Yakub, Razzak et al., 2015). A previous study by Ahmad, Mohd Yusoff, Abd Razzak et al. (2015) had shown that Sunnah of Prophet had been manipulated in marketing and promotion of products. This study has been supported by Ramli and Md Ariffin (2016). These products are often a marketing plan for some entrepreneurs to underline the product. On the part of the producer, they tend to use these Islamic attributes to attract Muslim customers to buy their product. Besides, with these attributes, they may sell it at higher prices (Zain, 2013a; Ramli and Md Ariffin, 2016; Zin, 2017). The existence of food products using Islamic attributes at their label and packaging has increased nowadays. This trend has shown that there is high demand for the Islamic product from the consumer. However, some dangers come with this uncontrolled practice. Hence, there is a need to study the types of misuse. This study was aimed 
to investigate the extent to which the use of Islamic attributes impacts the consumer and Islamic dignity.

\section{Materials and method}

A comprehensive search of the literature (magazines, books, journals, newspapers, and conference papers) through the early $2013 \mathrm{~s}$ to 2019 was carried out to collect relevant information and data. The materials not only limited to the English language but also covers Malay language materials. The keywords searched were 'Prophetic Food,' 'Sunnah food,' 'Ruqyah,' and 'misuse of religion.' The data were grouped into separate themes among others; the concept, current issues, types of use, contributing factors and the effects of the use.

\section{Results and discussion}

\subsection{Halal in Islam}

The term "halal" refers to the area of living arrangements of Muslims guided by halalan tayyiban, namely purity, hygiene, and healthy living, as well as halal (Mohamed Jusoh, 2001; Halim Ahmad, 2001). Halal is an Arabic word name. The basic halla, yahillu, hillan, which means free, release, break, dissolve, and allow (Dahlan, 1997). Terms halal opposed to illegal or out of something illegal (Wizarah al-Awqaf, 1990). According to Kamus Dewan (2005), halal is well defined as halal law permits an act is done (in Islam), legal (not forbidden by Islam), permitted and allowed. Literally, the halal means permitted, while also something illegal is prohibited. Halal food products alone are not sufficient but must include aspects of "good" (tayyib) that is clean, safe, and quality. Since the production of a food product comprising a particular process, starting from the selection, preparation of materials, manufacturing, production, storage, transportation, distribution until the product is presented to the consumer, then the "halal" should cover the whole network starting from its source (Soraji et al., 2017). According to al-Qaradawi (1994), something that is required, that no binding ban and allowed someone to do so by legislation. Halal is something that is a must and allowed by Islamic law (alAwqaf Wizarah, 1990). Al-Ghazali (1998) and AlQaradawi (2002) also clarifies the meaning of halal, which covers all major sources of human food either from animals, plants, natural materials, chemicals and microorganisms contained between lawful and unlawful law. The halal and haram debate also involve elements of biotechnology in food products and other personal goods, such as clothing, toiletries, and cosmetics. Based on the definition of the language and terminology, it can be concluded that the halal refers to something legal in Islamic law for humans to eat, use, and consume (Wahab and Azhar, 2014).

\subsection{Concept of trademark and labelling}

\subsubsection{Trademark}

A trademark is a sign capable of distinguishing the goods or services produced or provided by one enterprise from those of other enterprises. Any distinctive words, letters, numerals, drawings, pictures, shapes, colours, logo types, labels, or combinations used to distinguish goods or services may be considered a trademark. In some countries, advertising slogans are also considered trademarks and may be registered as such at national trademark offices. Under the Trade Mark Act 1976, "trademark" means, a mark used or proposed to be used concerning goods or services for indicating a connection in the course of trade between the goods or services and a person having the right either as proprietor or as a registered user to use the mark. Whether with or without an indication of the identity of that person. Whereas under the same Act, "mark" was defined as includes a device, brand, heading, label, ticket, name, signature, word, letter, numeral or any combination thereof. The main function of a trademark is to enable consumers to identify a product (whether a good or a service) of a particular company to distinguish it from other identical or similar products provided by competitors. Consumers who are satisfied with a given product are likely to buy or use the product again in the future. For this, they need to be able to distinguish easily between identical or similar products (WIPO, 2006).

Professor Robert G. Bone explains, trademark law's "core mission, as it is understood today, is to facilitate the transmission of accurate information to the market" (Desai, 2012). Trademark law thus clings to the model of the firm as the one with the exclusive power to develop the brand and to control its meaning. Trademarks enhance the economic efficiency of the marketplace by "lessening consumer search costs by making products and producers easier to identify in the marketplace," and "encouraging producers to invest in quality by ensuring that they produced, and not their competitors, reap the reputation-related rewards of that investment (Desai, 2012).

\subsubsection{Label}

A label is intended to help consumers differentiate the labelled product from otherwise similar products. A label calls to consumers' attention to the desirable attributes of the product. When a firm labels its product, it assumes that the information it provides is important to consumers and that they will respond by changing their purchase decisions (Golan et al., 2001). Teisl and Roe (2016) define product labelling as any policy instrument of a government or other third party that somehow regulates the presentation of product-specific 
information to consumers. This information might describe the use characteristics of the product, such as price, taste, and nutrition, or non-use characteristics, such as the environmental impact or moral/ ethical elements surrounding the product's manufacturing process. Simply stated, labelling policies can circumvent these market inefficiencies by making the information initially held by the firm also available to the consumer.

\subsection{Issues in food product labelling and marketing}

A research done by Osman et al. (2019) has categorized the use of Islamic elements into five categories which are first Quran-related verses such as Ruqyah where Quranic verses are claimed to be recited or written on specific products. Secondly Sunnah-related such as using the term Prophetic foods or the word Sunnah itself, and thirdly by using Islamic icons and pictures such as pictures of mosques. Fourthly, by using Islamic performance of worships such as prostration in prayers and the last category is Islamic or Muslim names such as Tok Guru, Pak Sheikh and Ahmad. However, the researchers would like to add another category such as by using Jawi writings in the label or trademark, and it can be regarded as misuse of Islamic attributes in marketing. For the first category, many products are available on the market. For example, 'Kismis 30 juzu' Al-Quran" (raisins which have been recited 30 juzu' of Quranic verses), 30 juzu' mineral water, air pinggan putih (mixture of water and saffron with a special technique of writing Quranic verses using saffron liquid on a white plate). These products are believed to have special attributes in healing particular disease and may give certain benefit to whom consume them. For the second category, the word Sunnah or the Hadith of Prophet has been used on the label and these products are the most common type that can be found in the market. The products usually contain either dates, honey, goat's milk, habbatus sauda, raisins, olive oil or combination of them and some other ingredients. In some instances, these products are back up with the text of hadith (Ramli and Md Ariffin, 2016). For the third category, Islamic icon and logo such as, crescent and Kaabah were used as trademark on the label. For examples Mi Cap Masjid and Kopi Cap Songkok. Next category is where Muslim name and Islamic term being used for example Pau Ahmad, Kopi Pak Sheikh and Kopi al-Ambiyak. In 2014, there was a case where a man was dead after drinking these coffee (Shagar et al., 2014). It was discovered that the coffee was banned by the Ministry of Health for containing sildenafil and tadanafil, which are often claimed to be able to increase sexual performance. The Ministry of Health has confirmed that the coffee has been banned in early 2014 (Shagar et al., 2014). This case was upsetting since it uses Islamic attributes as their trademark. On the next category, is where the Islamic performance of worship such as tawaf has been used as a marketing strategy. A good example is the service of valet doa where the person offers a service of making doa in front of Kaabah with certain amount of payment by the customer. This practice has been condemned by the Director of JAKIM (Mutalib, 2017; Zin, 2017). The last category is where Jawi or Arabic writings were used on the labelling. Some of the products do not get the halal certification from JAKIM and this practice has been forbidden by Malaysian Community Enterpreneur Development (MCED) as it may confuse the consumer as to the halal status of the product (Sahril, 2019).

\subsection{Current problems and effects}

The issue of using Islamic attributes in labelling has emerged since 2013. This practice was due to the existence of a huge range of health products, for example, drinks, cosmetics, and it includes the alternative health treatment that uses these Islamic attributes. This scenario is wide spreading because the current interest of people towards Islam is so high that whatever it is said is the efficacy of the Qur'an, so many believe that without prior inspection (Ahmad, Yakub, Razzak et al., 2015). Products based on "Sunnah food" or Ruqyah food and drink (being read al-Qur'an verses onto them) are often referred to as the best food. Additionally, there are also products that are produce by using zam-zam water as a mixed ingredient. However, the zam-zam water that is used as a mixture of ingredients is in small quantities. The product is then labeled with zam-zam water as an ingredient. These products are often a marketing plan for some entrepreneurs to underline the product. What is troubling is the possibility of fraud with the reason that the product is more blessed and effective because it is recited alQur'an, recitation, or prayer (Ramli and Md Ariffin, 2016). The previous head Imam of the National Mosque Datuk Hassan Mahmud acknowledged that there were parties who used the Qur'an with the intention of leveraging the products they produce (Zain, 2013a). Consumers are advised not to be easily influenced by the sale of products that use the Qur'anic texts as there are parties who use it to leverage the business. The consumer should not buy the product merely because of the label and fearing that it may harm the consumer (Zain, 2013a). Even though the public has been warned, the demand towards these products was still high. They believed that these products that have been read Qur'anic verses or Ruqyah and Sunnah food has its advantages and may cure certain disease (Zain, 2013b). On the part of the producer they tend to use these Islamic attributes to attract Muslim customers to buy their product. Besides, with these attributes they may sell it at higher prices 
(Zain, 2013a; Ramli and Md Ariffin, 2016; Zin, 2017) Consumption of sunnah food had become trend. Whether in supermarkets, direct sales, or online marketing, there are many supplements based on sunnah food available to the public. It becomes the latest trend due to high demand, especially among Muslims. It gives a new dimension in the world food market. Our society seems to have the initial force to find an alternative in health care. This situation eventually led to the innovation of sunnah food. Dates, for example, have been innovated into chocolate, herbal essence, coffee, cordial, and 3 in 1 drink (Othman et al., 2016). More ominously if the ingredients have not been checked it will endanger people's life. This was so, as reported by Md Denin and Kamarudin (2018) about a case recently happened in Penang, where a non-Muslim couple of husband and wife has been caught producing health products known as 'Jus Sunnah.' This product has been tested and confirmed positive of containing scheduled drugs, i.e., steroid dexamethasone and prednisolone, which was prohibited by the Ministry of Health. This product was claimed as able to cure joint pain, vein, and numb and the like, and it has been sold at the market at a price ranging between RM75 to RM130 (Md Denin and Kamarudin, 2018). This practice was a clear act of misused of Islamic attributes, i.e. the word 'Sunnah' as their trademark on their packaging to deceive the Muslim consumers and to get more profit. Moreover, they claimed that the ingredients were 100 percent of natural juice from selected fruits, but it turned out that they were from combination of flavored powder, caramel, pipe water, and chemical substance (Md Denin and Kamarudin, 2018).

In addition to allegations of Sunnah food products of Prophet Muhammad, there is also the misuse of dhaif and maudhu' hadiths for the pursuit of product sales. Ramli and Md Ariffin, (2016) have conducted a study on the misuse of the Prophet's hadith in consumer products in the market. Attempts to exploit the hadith of the Prophet SAW as product tools of marketing should be tackled by the authorities. This is because if the product does not give benefit to the consumer, the risk of the hadith of the Prophet (s) will be denounced. Thus, producers need to be responsible for the use of the "Sunnah product" label because it risks the negative impact on Sunnah position as the second source of authority in Islam.

On the other hand, in some cases, this Sunnah food might not be suitable for certain health conditions. For example, Sunnah food which based on dates and raisins, which high in sugar might not be suitable for a diabetic person. It may cause harm instead of curing the person. Thus, a comprehensive scientific research should be conducted on the production, handling, the efficacy of Sunnah food, safety, and quality control on all Sunnah food (Ahmad et al., 2015). Possibly, with the mixture of Sunnah food with other ingredients, the chemical composition and nutritional value of food is also changed compared to the original material itself. Is it fair for the food product to be claimed as the Sunnah food? The quantity of a specific type of food product should also be taken into account. The easiest example is the dates of juice. If the dates juice sold is not merely contained dates, but also added sugar, is it good for health? (Othman et al., 2016)

It is worrying that the manufacturer will use the basis of Sunnah food to achieve commercial value per se by totally ignore the impact on health. Not to mention the duplication by explicitly incorporate into a product added sugar, non-dairy creamer, and malt then labeled as sunnah food (Othman et al., 2016).

\subsection{Fatwa rulings}

In response to the use of ayat Ruqyah, Quranic verses, and related to it, the National Fatwa Council for Islamic Religious Affairs Malaysia (Muzakarah Majlis Fatwa Kebangsaan Bagi Hal Ehwal Ugama Islam Malaysia) decreed that this scenario is very dangerous to the religious belief and it may lead to syirik. The products and the chants have no power to heal except Allah (Berita Harian Online, 2016) Muslims need to carefully manage their lives so as not to deviate from the established grounds. Religion should not be a channel for wealth and political gain, and thus people need to reject such exploits (Zin, 2017).

Due to these worrying scenarios, the Department of Islamic Development Malaysia (JAKIM) has made a move to control this matter. Companies and applicants of the Malaysian Halal Certification are not allowed to use the term 'ayat Ruqyah', 'Sunnah food' and the like on labelling, advertising and promotion of products that are sought for halal certification. This is due to the circular on the regulation was enforced on 15 February 2016 after the Trade Descriptions (Halal Certification and Marking) Order 2011 (Mutalib, 2016).

However, this prohibition is not exhaustive. the prohibition only limited to the use of the word 'Ayat Ruqyah' and 'Makanan Sunnah', and the circular is silence on the usage of other Islamic attributes.

\section{Conclusion}

There are principles in Islam called Sadd Zarai', which means harms should be eliminated. Based on Maqasid Syar'iyyah that is hifzu ad-din or the preservation of religion, these activities of misuse should 
be controlled by the government to avoid any harm in the future. The government should set up a clear guideline to control the use of Islamic attributes in labelling. Islam should not be used for commercial purposes and be exploited by irresponsible parties. Its dignity should be upheld in all times and situations and should not be open to any exploitation.

\section{Acknowledgment}

The authors wish to thank the Universiti Sains Islam Malaysia for the research grant to complete the project entitled "Laws relating to Products Labeling and Marketing: Proposed Amendments according to Maqasid Syariah," of which this paper is part of the output.

\section{References}

Ab Talib, M.S. and Mohd Johan, M.R. (2012). Issues in Halal Packaging: A Conceptual Paper. International Business and Management, 5, 94-98. https:// doi.org/10.3968/j.ibm.1923842820120502.1080

Ahmad, K., Yakub, M., Razzak, M. A., Izham, S.S. and Ariffin, M.F.M. (2015). Salah Faham Terhadap Istilah "Makanan Sunnah" Dalam Kalangan Masyarakat Islam di Malaysia: Satu Analisis. In Salah Faham Terhadap Sunnah: Isu dan Penyelesaian. $1^{\text {st }}$ ed. Kuala Lumpur: Jabatan alQuran dan Al-Hadith, Akademi Pengajian Islam. [In Bahasa Malaysia].

Ahmad, K., Mohd Yusoff, M.Y.Z., Abd Razzak, M.M., Raja Yusof, R.J., Fauzi, N., Awang, K., Othman, R. and Md. Ariffin, M.F. (2015). Kriteria Dalam Penilaian Terhadap Istilah Pemakanan Sunnah: Antara Realiti dan Pengamalan Dengan Fakta Berasaskan Fiqh Daripada Nas. In Prosiding Seminar Fiqh Semasa (SeFis) 2015, p. 53-64. Nilai: Usuli Faqih Research Centre.

Berita Harian Online. (2016). Label rawatan, makanan sunah gugat akidah. Retreived from Berita Harian Online Website: https://www.bharian.com.my/ node/129206

Dahlan, A.A. (1997). Ensiklopedia Hukum Islam. Vol. 2. Jakarta: PT Ichtiar Baru Van Hoeve.

Desai, D.R. (2012). A Brand Theory of Trademark Law. SSRN Electronic Journal, 1585327(1585327). https://doi.org/10.2139/ssrn.1585327

Deuraseh, N. and Mohd Tohar, S.N.A. (2008). Healing Through Ruqyah (incantation) With Special Focus on the Perception of Malay-Muslim Society in Kelantan and Terengganu on Ruqyah as an Alternative Way of Healing in Malaysia. Journal of the International Society for the History of Islamic Medicine, 6-7, 50-54.
Golan, E., Kuchler, F., Mitchell, L., Greene, C. and Jessup, A. (2001). Economics of Food Labeling. Agricultural Economic Report No. 793. United States: Economic Research Service, U.S. Department of Agriculture.

Ismail, M. (2012). Penyelewengan Akidah Dan Syariat Dalam Perkhidmatan Rawatan Alternatif: Isu Kepenggunaan dan Akidah Umat Islam. Retrieved from Pusat Rawatan Islam Manarah website: http:// primanara.blogspot.my/2012/03/penyelewenganakidah-dan-syariat-dalam_19.html

Kamus Dewan, 2005. Edisi Ke-3. Kuala Lumpur: Dewan Bahasa dan Pustaka. [In Bahasa Indonesia].

Md. Denin, M.J.A. and Kamarudin, F. (2018). Produk Sunnah Tauke Haram. Harian Metro.

Mutalib, Z.A. (2016). Larangan guna 'ayat ruqyah, "makanan sunnah" bagi iklan produk. Retrieved from Berita Harian Online website: https:// www.bharian.com.my/node/128625. [In Bahasa Malaysia].

Mutalib, Z.A. (2017). Valet doa di Makkah cemar kesucian Islam - JAKIM. Berita Haran Online

Osman, S., Ahmad, M.H. and Jalil, A. (2019). Penggunaan unsur Islam dalam Perniagaan: Analisa Dari Perspektif Syariah. Journal of Islamic Social Sciences and Humanities, 17(Special Edition), 3951.

Othman, R., Sayidah, A.B. and Ahmad, K. (2016). Legal issues in sunnah food labeling. What's in a name? In Mohd Yusoff, M.Y.Z., Ahmad, K. and Abd Razzak, M. (Eds.) Penyelidikan Tentang Makanan: Perspektif Nabawi dan Saintifik, p. 139-157. Kuala Lumpur: Department al-Quran and al-Hadith, APIUM.

Ramli, M.A. and Jamaludin, M.A. (2016). Budaya Makanan dan Pemakanan Halal dalam Kalangan Masyarakat Melayu Menurut Perspektif Islam. In Mohd Yusoff, M.Y.Z., Ahmad, K. and Abd Razzak, M. (Eds.) Penyelidikan Tentang Makanan: Perspektif Nabawi dan Saintifik, p. 195-206. Kuala Lumpur: Department al-Quran and al-Hadith, APIUM.

Ramli, M.A. and Md Ariffin, M.F. (2016). Penyalahgunaan Sunnah Nabi Dalam Pelabelan Dan Promosi Produk Halal. In Mohd Yusoff, M.Y.Z., Ahmad, K. and Abd Razzak, M. (Eds.) Penyelidikan Tentang Makanan: Perspektif Nabawi dan Saintifik, p. 129-138. Kuala Lumpur: Department al-Quran and al-Hadith, APIUM.

Sahril, N.A. (2019). Larangan guna tulisan Jawi pada produk bukan Muslim. Retrieved from Sinar Harian website: https://www.sinarharian.com.my/ article/44044/BISNES/MCED

Shagar, L.K., Ng, S.H. and Raman, A. (2014). Favourite- 
coffee-turns-deadly-Man-dies-hours-after-insistingon-drinking-banned-beverage. Retrieved from The Star Online Website: http://www.thestar.com.my/ News/Nation/2014/09/20/Favourite-coffee-turnsdeadly-Man-dies-hours-after-insisting-on-drinkingbanned-beverage/

Schiffman, L. and Kanuk, L.L. (2010). Consumer Behavior, Global Tenth Edition. United State of America: Pearson Education, Inc.

Soraji, A.J., Awang, M.D. and Yusoff, A.N.M. (2017). Gaps in The Legislation Halal in Malaysia: A Study of Literature, presented at the Proceedings of ADVED $20162^{\text {nd }}$ International Conference on Advances in Education and Social Sciences 10-12 October 2016, Istanbul, Turkey. Retrieved from http://www.ocerint.org/adved16_e-proceedings/ papers/180.pdf

Teisl, M. and Roe, B. (1998). The Economics of Labeling: An Overview of Issues for Health and Environmental Disclosure. Agricultural and Resource Economics Review, 27(2), 140-150.

Trade Marks Act 1976. (2006). Act 175. (MY).

Wahab, H.A. and Azhar, A. (2014). Halalan Tayyiban Dalam Kerangka Perundangan Malaysia. Kanun, 26, 103-120.

World Intellectual Property Organization (WIPO). (2006). Making a Mark - An Introduction to Trademarks for Small and Medium-Sized Enterprises. Switzerland: WIPO.

Zain, I.M. (2013a). Hati-hati dengan produk guna ayat Al-Quran. Retrieved April 23, 2019 from Astro Awani website: http://www.astroawani.com/beritamalaysia/hati-hati-dengan-produk-guna-ayat-alquran-18415. [In Bahasa Malaysia].

Zain, I.M. (2013b). Produk Guna Ayat Al-Quran masih dapat Sambutan. Retrieved from Astro Awani website: http://www.astroawani.com/beritamalaysia/produk-guna-ayat-al-quran-masih-dapatsambutan-18527. [In Bahasa Malaysia].

Zin, A.M. (2017). Eksploitasi dalam ajaran agama. Retreived from Berita Harian Online website: https:// www.bharian.com.my/node/266750 